\title{
THE DETERMINATION OF FATTY ACIDS COMPOSITION AND OIL QUALITY FACTORS OF SOME PEANUT VARIETIES HAVING DIFFERENT MARKET TYPES AT DIFFERENT HARVESTING TIMES IN MAIN AND DOUBLE CROP GROWING SEASONS IN MEDITERRANEAN REGION
}

\author{
Halil BAKAL ${ }^{1}$, Halis ARIOGLU ${ }^{1 *}$ \\ ${ }^{1}$ Cukurova University, Faculty of Agriculture, Dep. of Field Crops, Adana-Turkey \\ *Corresponding author: halis@cu.edu.tr
}

\begin{abstract}
The objective of this study was to determine the fatty acids composition and oil quality factors of some peanut varieties having different market types at different harvesting times in main and double crop growing seasons in Mediterranean region. This study was conducted in the experimental area of the Cukurova University Faculty of Agriculture Department of Field Crops as a main and double crop in 2015 and 2016. The experimental design was a split plot with three replications. Five peanut varieties, including Halisbey, NC-7, G.Green, Florispan and G.Red, belonging to four different market types, were used as plant material in this research. According to a two-year average, the differences between the peanut varieties were significant for the oil content, oleic, linoleic, palmitic, stearic and lignoceric acids percentage and oil quality values at different harvesting times in the main and double crop growing season. The results indicated that the data belonging to oil content, oleic and stearic acids percentage were increased when the harvesting was delayed, and that linoleic, palmitic and lignoceric acids percentage of seed was decreased. Stearic acid and oleic acid percentage and $O / L$ ratio was higher in main crop growing season and oil content, linoleic acid percentage and iodine value was higher in double crop growing season.
\end{abstract}

Keywords: Peanut, harvesting time, fatty acid, oil quality factors

\section{INTRODUCTION}

Peanut (Arachis hypogaea L.) is the fifth most important oilseeds crop in the world with production of approximately 47 million tons per year (Anonymous, 2017a). Peanut seeds contain $35-56 \%$ oil and $25-30 \%$ protein and 9.5-19.0\% carbohydrate on a dry seed basis (Savage and Keenan, 1994). For this reason, it is an important source of edible oil and protein for human nutrition in the world. About two-thirds of total peanut production is crushed for oil and the remaining one-third is used in confectionery products in the world (Dwivedi et al., 1993). In addition, peanuts are a rich source of other nutrients such as minerals ( $\mathrm{P}, \mathrm{Ca}, \mathrm{Mg}, \mathrm{Mn}$ and $\mathrm{K}$ ) and vitamins (E, K and B groups) (Hassan and Ahmed, 2012 and Gulluoglu et al., 2017).

Isleib et al. (2008) and Arioglu et al. (2018) reported that the oil content is an important quality characteristic in peanut seed. The oil content of peanut seed influences by genotypic variation, growing conditions and maturity. Lue et al. (1997) indicated that the oil content of peanut varieties was increased by delaying the harvesting times. Canavar and Kaynak (2013) reported that oil content and Oleic acid/Linoleic acid (O/L) ratios were increased by delaying the harvesting time. Sarkees (2015) reported that oil percentage was increased from 39.5 to $44.3 \%$ when the planting delayed to June 3 from April 22.

The nutritional and storage qualities of peanut are determined by its fatty acids composition. Peanut oil contains saturated and unsaturated fatty acids. The major fatty acids in peanuts are palmitic (16:0), stearic (18:0), oleic (18:1), linoleic (18:2), arachidic (20:0), eicosenoic $(20: 1)$, behenic (22:0) and lignoceric (24:0) acids. Oleic and linoleic acids are two important unsaturated fatty acids and both of them comprised about $80 \%$ of fatty acid composition. The rest of fatty acids are saturated fatty acids $(20 \%)$. Peanut cultivars varied in their fatty acid composition (Ahmed and Young, 1982).

Oil content and fatty acid composition of peanut has been studied in different cultivars and different environments and it has been reported that the oil content of peanut cultivars varied between 37.9-56.3\%oleic acid 37.7-82.2\%, linoleic acid 2.9-41.5, palmitic acid 9.6$13.2 \%$, stearic acid 1.6-3.7\%, arachidic acid 1.2-1.7\%, behenic acid 1.2-3.5\% and iodine value varied between 88.6 to 105.4 (Dwivedi et al., 1996; Ozcan and Seven, 2003; Mozingo et al., 2004; Yav et al., 2008; Onemli, 2012; Chaiyadee et al., 2013; Mzimbiri et al., 2014; Escobedo et al., 2015 and Golukcu et al., 2016). 
The nutritional and storage qualities of groundnut depend on the relative proportion of saturated and unsaturated fatty acids in the oil. Peanut oil is rich in unsaturated fatty acids such as oleic and linoleic acids (Escobedo et al., 2015). These fatty acids have been related to a reduced cardiovascular disease risk. The oleic acid (a monosaturated fatty acid) decreased low-density lipoprotein (LDL) cholesterol levels without reducing good high-density lipoprotein (HDL) cholesterol. Monosaturated fatty acids may decrease platelet aggregation and increase fibrinolysis, thereby protecting against thrombogenesis (Kris-Etherton, 1999). However, studies have shown that linoleic acid is the most effective polyunsaturated fatty acid for lowering serum cholesterol and the best for preventing cardiovascular disease (Harris et al., 2008 and Mzimbiri et al., 2014).

Young and Worthington (1974), Yav et al. (2008), Chaiyadee et al. (2013), Chamberlin et al. (2014) and Escobedo et al. (2015) reported that the ratio of oleic acid to linoleic acid (O/L ratio) and iodine value (IV) determine the nutritional quality, storability and shelf-life of peanut oil and its products. A high oleic to linoleic $(\mathrm{O} / \mathrm{L})$ acid ratio $(>10: 1)$ in peanut results an increased self life (up to 10 times) and improved flavor when compared to a normal $\mathrm{O} / \mathrm{L}$ ratio $(1.5: 1)$. In addition, the iodine value was used to determine the degree of unsaturated fatty acid and the stability of peanut oil. High O/L ratio and low IV value generally indicate good stability and long shelf-life (Worthington et al., 1972 and Young and Manson, 1972).

Hashim et al. (1993), Isleib et al. (2008), Shin et al. (2010), Gulluoglu et al. (2016) and Arioglu et al. (2018) indicated that the fatty acid composition of peanut oils varies significantly by genotype, seed maturity, production year and planting date, geographic location of production, and environmental factors including temperature and other seasonal effects.

Andersen and Gorbet (2002), Gulluoglu et al. (2017) and Arioglu et al. (2018) reported that seed maturity can also influence the fatty acid composition of peanut. The actual impact of seed maturity is dependent on genotype, climatic conditions, and genotype/climate interactions. Lower temperature during the seed development normally is associated with more unsaturated oil due to the increased activity of oleate desaturase, which promotes the synthesis of linoleic acid. In general, oleic acid increases and linoleic acid decreases with seed maturity. The increase in oleic acid with seed maturity is normally accompanied by a decrease in palmitic, linoleic, arachidic, eicosenic, behenic and lignoceric acid. Bovi (1982), Raheja et al. (1987) and Onemli (2012) reported that there was a negative correlation between oleic acid and linoleic acid. Holaday and Pearson (1974) found that higher temperatures during the last 4 weeks before harvest resulted in higher oil and oleic acid content and correspondingly higher $\mathrm{O} / \mathrm{L}$ ratios.

Peanut is broadly categorized into four market types such as Runner, Valencia, Spanish and Virginia. Each market type has distinct size, flavor, and nutritional composition (Arioglu, 2014). Fatty acid composition of peanut oils is not constant. The fatty acid composition of peanut oil varies depending on growing seasons, varieties and harvesting times. Peanut has been grown as a main and double cropped after a small grain harvest in the Cukurova region in Turkey. The objective of the study was to determine saturated and unsaturated fatty acids composition and oil quality $(\mathrm{O} / \mathrm{L}$ and IV) of some peanut varieties having different market types at different harvesting times in main and double crop growing seasons in Mediterranean region in Turkey.

\section{MATERIALS AND METHODS}

\section{Material}

This experiment was conducted in 2015 and 2016 as a main and double crop in Mediterranean region in Turkey. Halisbey (Virginia), NC-7 (Virginia), G.Runner (Runner), Florispan (Spanish) and G.Red (Valancia) peanut varieties belonging to different market types were used as a plant material in this research. These materials were obtained from Field Crops Department, University of Cukurova.

This study was conducted in Adana province in Turkey and in this region, winters are mild and rainy, whereas summers are dry and warm, which is a typical of a Mediterranean climate. The climate data during the 2015-2016 growing period and long term (LT) average (1982-2015) was shown in Table 1.

Table 1. The climate data during the growing period in 2015, 2016 and long term (LT) average (1982-2015) (Anonymous, 2017b)

\begin{tabular}{lccccccccc}
\hline Months & \multicolumn{3}{c}{ Average temperature $\left({ }^{\circ} \mathbf{C}\right)$} & \multicolumn{3}{c}{ Precipitation $(\mathbf{m m})$} & \multicolumn{3}{c}{ Relative humidity $(\%)$} \\
& $\mathbf{2 0 1 5}$ & $\mathbf{2 0 1 6}$ & $\mathbf{L T}$ & $\mathbf{2 0 1 5}$ & $\mathbf{2 0 1 6}$ & $\mathbf{L T}$ & $\mathbf{2 0 1 5}$ & $\mathbf{2 0 1 6}$ & $\mathbf{L T}$ \\
\hline April & 16.9 & 20.5 & 17.5 & 21.5 & 1.8 & 51.3 & 61.2 & 59.2 & 67.6 \\
May & 22.5 & 22.6 & 21.7 & 65.7 & 87.9 & 47.3 & 64.8 & 69.3 & 67.3 \\
June & 25.0 & 27.1 & 25.6 & 4.8 & 45.6 & 20.4 & 69.6 & 66.1 & 68.0 \\
July & 28.4 & 29.5 & 28.2 & 0.4 & 0.2 & 6.3 & 69.8 & 67.5 & 71.4 \\
August & 30.0 & 30.9 & 28.7 & 10.9 & 0.0 & 5.6 & 63.4 & 69.0 & 70.8 \\
September & 28.4 & 26.3 & 26.1 & 13.0 & 34.8 & 17.8 & 64.8 & 61.8 & 63.2 \\
October & 23.4 & 23.1 & 21.6 & 32.1 & 0.0 & 42.1 & 63.7 & 56.4 & 59.5 \\
\hline
\end{tabular}


The mean monthly air temperature during the research period (April-October) was varied between 16.9 and 30.0 ${ }^{\circ} \mathrm{C}$ in 2015 , whereas it was 20.5 and $30.9{ }^{\circ} \mathrm{C}$ in 2016 . The average air temperature was the higher during the research period in both years than long term average temperature. The total rainfall was $148.4 \mathrm{~mm}$ and $170.3 \mathrm{~mm}$ during the growing period in 2015 and 2016, respectively. The average relative humidity was ranged from $61.2 \%$ to $69.8 \%$ in 2015 and $56.4 \%$ to $69.3 \%$ in 2016. The differences between the years and long term (1928-2018) for the climate data were not found very significant (Table $1)$.

The soil texture was clay loam. The soil tests indicated that $\mathrm{pH}$ of 7.7 with high concentrations of $\mathrm{K}_{2} \mathrm{O}$ and low concentrations of $\mathrm{P}_{2} \mathrm{O}_{5}$. In addition, the organic matter and nitrogen content of the soil were very low. The lime content was $20.1 \%$ in the soil.

\section{Method}

The experiment was designed as a split plot design (harvesting times as main plots and varieties as subplots) with three replications. $300 \mathrm{kgha}^{-1}$ of Di-ammonium phosphate (54 kgha-1 $\mathrm{N}, 138 \mathrm{kgha}^{-1} \mathrm{P}_{2} \mathrm{O}_{5}$ ) fertilizer was applied and incorporated to soil before planting. Ammonium nitrate $(33 \% \mathrm{~N})$ at the rates of $400 \mathrm{kgha}^{-1}$ was applied two times; before first (beginning of flowering) and second (pod formation) irrigation $\left(200 \mathrm{kgha}^{-1}+200\right.$ $\mathrm{kgha}^{-1}$ ) in each years. Individual plots consisted of 4 rows $5.0 \mathrm{~m}$ long and $70 \mathrm{~cm}$ apart. The seeds were sown in line manually by hand on first week of April (5 April) and with 70x15 cm distance in both years. During the growing period, recommended pesticides and fungicides were applied to control insects and diseases. The remaining cultural practices were applied during the growing period. The plants were harvested by hand at five different times with ten days intervals after sowing such as 130 DAS, 140 DAS, 150 DAS, 160 DAS and 170 DAS in main crop growing period and 110 DAS, 120 DAS, 130 DAS, 140 DAS and 150 DAS in double crop growing period at the beginning of September in each year.

Data collection and analysis: The data belonging to oil content and oil quality characteristics such as fatty acids composition, $\mathrm{L} / \mathrm{O}$ and Iodine values (IV) were recorded in each harvesting time with ten days intervals (Arioglu et al., 2018).

The plants harvested by hand when the $60 \%$ of the pods are matured in both growing seasons. Total oil in the seed was determined in a Soxhlet extractor, using petroleum ether as solvent.

Determination of fatty acids composition: Fatty acid methyl esters were prepared according to AOCS (1989), method Ce 2-66 and analyzed with HP 6890 Series II Gas Chromatograph (GC) (Hewlett-Packard Company,
Wilmington, DE, USA) equipped with a flame ionization detector and auto sampler. A fused silica capillary column SP $2340(60 \mathrm{~m} \times 0.25 \mathrm{~mm}$ i.d. $)$ with a film thickness of $0.25 \mu \mathrm{m}$ (Supelco, Taufkirchen, Germany) was used. Injection, detector, and oven temperatures were 250, 260, and $190^{\circ} \mathrm{C}$, respectively. Nitrogen was used as a carrier

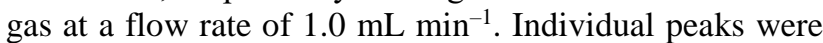
identified by comparing the retention times with grain fatty acid methyl esters.

Iodine values $(\mathrm{IV})=[(\%$ oleic acid $\times 0.8601)+(\%$ linoleic acid $x$ 1.7321)] and Oleic acid/Linoleic acid (O/L) ratio $=[\%$ oleic acid (18:1)/linoleic acid (18:2) $]$ of the peanut oils were calculated using the equation given by Chowdhury et al. (2015)

The data were statistically analyzed by using JUMP 8.1.0 package program with split plot design. The Least Significant Differences (LSD) test was used to compare the treatments at 0.05 level.

\section{RESULTS AND DISCUSION}

\section{Oil Content and Saturated Fatty Acids Composition}

The two years average values belonging to oil content and important saturated fatty acids composition of peanut varieties at different harvesting times and growing seasons have been presented in Table 2 .

\section{Oil Content}

As it can be seen from Table 2, statistical significant differences were observed between harvesting times for oil content in a two years average. According to the two years average, the oil content values varied between 45.80 and $48.98 \%$ in main crop and between $46.06-49.35 \%$ in double crop growing season. The oil content of the peanut varieties was increased when the harvesting time delayed in both growing seasons. Isleib et al. (2008) indicated that the oil content of peanut seed influences by genotypic variation, growing conditions and maturity. Lue et al. (1997), Canavar and Kaynak (2013), Gulluoglu et al. (2016) and Arioglu et al. (2018) reported that the oil content of peanut varieties was increased by delaying the harvesting times. Court et al. (1984) reported that the oil percentage was $45.8 \%$ in 2 September it was increased to $47.8 \%$ in 12 October. Caliskan et al. (2008) reported that while the oil percentage was $49.5 \%$ when the seed harvested $120 \mathrm{DAS}$, it was increased to $52.6 \%$ harvesting time was delayed to 160 DAS. Arioglu et al. (2018) reported that while the oil percentage was $47.4 \%$ when the seed harvested 149 DAS, it increased to $49.8 \%$ harvesting time was delayed to 170 DAS in main crop growing season. The oil content of the varieties was higher in double crop growing season than main crop growing season in a two year average. Sarkees (2015) reported that oil percentage was increased from 39.5 to $44.3 \%$ when the planting delayed to June 3 from April 22. 
Table 2. The two years average values belonging to oil content and saturated fatty acids composition of some peanut varieties at different harvesting times in main and double crop growing seasons.

\begin{tabular}{|c|c|c|c|c|c|c|c|c|c|}
\hline \multicolumn{2}{|c|}{ Harvesting Times (A) } & \multicolumn{2}{|c|}{$\begin{array}{c}\text { Oil Content } \\
(\%)\end{array}$} & \multicolumn{2}{|c|}{ Palmitic Acid (\%) } & \multicolumn{2}{|c|}{ Stearic Acid (\%) } & \multicolumn{2}{|c|}{$\begin{array}{c}\text { Lignoceric Acid } \\
(\%)\end{array}$} \\
\hline Main Crop & $\begin{array}{c}\text { Double } \\
\text { Crop }\end{array}$ & $\begin{array}{l}\text { Main } \\
\text { Crop }\end{array}$ & $\begin{array}{c}\text { Double } \\
\text { Crop }\end{array}$ & $\begin{array}{l}\text { Main } \\
\text { Crop }\end{array}$ & $\begin{array}{l}\text { Double } \\
\text { Crop }\end{array}$ & $\begin{array}{l}\text { Main } \\
\text { Crop }\end{array}$ & $\begin{array}{l}\text { Double } \\
\text { Crop }\end{array}$ & $\begin{array}{l}\text { Main } \\
\text { Crop }\end{array}$ & $\begin{array}{c}\text { Double } \\
\text { Crop }\end{array}$ \\
\hline $130 \mathrm{DAS}$ & $110 \mathrm{DAS}$ & 45.80 & 46.06 & 10,73 & 10,78 & 3,01 & 2,80 & 1,80 & 1,82 \\
\hline 140 DAS & $120 \mathrm{DAS}$ & 46.49 & 46.81 & 10,59 & 10,55 & 3,06 & 2,85 & 1,72 & 1,72 \\
\hline 150 DAS & 130 DAS & 47.08 & 47.27 & 10,46 & 10,45 & 3,15 & 2,91 & 1,68 & 1,67 \\
\hline 160 DAS & $140 \mathrm{DAS}$ & 47.69 & 47.95 & 10,26 & 10,33 & 3,20 & 3,02 & 1,67 & 1,64 \\
\hline 170 DAS & $150 \mathrm{DAS}$ & 48.98 & 49.35 & 9,91 & 9,97 & 3,30 & 3,08 & 1,63 & 1,60 \\
\hline $\operatorname{LSD}\left(\% 5_{\mathrm{A}}\right)$ & & 0.137 & 0.167 & 0.005 & 0.007 & 0.002 & 0.002 & 0.08 & 0.02 \\
\hline \multicolumn{10}{|l|}{ Varieties (B) } \\
\hline Halisbey & & 47.72 & 48.06 & 9,62 & 9,49 & 3,15 & 2,96 & 1,70 & 1,80 \\
\hline $\mathrm{NC}-7$ & & 46.56 & 46.79 & 8,43 & 8,53 & 3,41 & 3,17 & 1,49 & 1,42 \\
\hline G. Green & & 49.25 & 49.48 & 10,52 & 10,55 & 2,36 & 2,24 & 1,85 & 2,00 \\
\hline Florispan & & 48.60 & 48.90 & 12,05 & 12,00 & 3,47 & 3,21 & 1,87 & 1,71 \\
\hline G.Red & & 43.91 & 44.20 & 11,32 & 11,52 & 3,33 & 3,09 & 1,60 & 1,54 \\
\hline $\operatorname{LSD}\left(\% 5_{\mathrm{B}}\right)$ & & 0.122 & 0.126 & 0.007 & 0,013 & 0,004 & 0,004 & 0,02 & 0,04 \\
\hline $\operatorname{LSD}\left(\% 5_{\mathrm{AxB}}\right)$ & & 0.273 & 0.282 & 0.016 & 0.015 & 0.005 & 0.005 & 0.04 & 0.05 \\
\hline
\end{tabular}

According to a two-year average, the differences between the peanut varieties for the oil content were found statistically significant in both growing seasons. The oil percentage values of the varieties varied between 43.91 and $49.25 \%$ in main crop and 44.20 and 49.48 in double crop growing season in a two year average (Table 2). The reason for the differences between the varieties for the oil content was them having different genotypes (Court et al., 1984; Sattayarak, 1997; Lu et al., 1997 and Canavar and Kaynak, 2013). The oil content was the highest in G.Green (49.25\% ve $49.48 \%$ ) and the lowest in G.Red $(43.91 \%$ ve $44.20 \%)$ in both growing seasons. Hassan et al. (2005), Yav et al. (2008), Isleib et al. (2008) Calıskan et al. (2008), Onemli (2012), Wang and Xu (2013), Gulluoglu et al. (2017) and Arioglu et al. (2018) reported that the oil percentage of the peanut varieties varies between $35-56 \%$ depending on genotype, seed maturity, growing season and growing conditions. The amount of oil in peanut seeds has been shown to vary with the cultivar, market type (runner, virginia, valancia or spanish) and the environment conditions under which the seeds were produced (Sanders et al., 1995). Interaction between the harvesting times and varieties for the oil percentage was found significant.

\section{Saturated Fatty Acids Composition}

The major saturated fatty acids in peanut oil are palmitic (16:0), stearic (18:0) and lignoceric (24:0) acids. According to a two-year results, significant differences were observed between harvesting times for palmitic, stearic and lignoceric acids. Palmitic acid percentage values varied between $9.91-10.73 \%$ and $9.97-10.78 \%$ in main and double crop growing seasons, respectively in a two year average. While the palmitic acid percentage was $10.73 \%$ and $10.78 \%$ at the early harvesting, it decreased to $9.91 \%$ and $9.97 \%$ when the harvesting delayed to 170 DAS and 150 DAS in main and double crop growing season, respectively (Table 2). The differences between the peanut varieties were statistically significant for the palmitic acid content in both growing seasons. The palmitic acid percentage varied between $8.43-12.05 \%$ in main crop and $8.53-12.00 \%$ in double crop growing seasons in a two-year average. There were no big differences between the growing seasons for the palmitic acid content in peanut varieties. According to a two-year average, the palmitic acid percentage was the highest in Florispan $(12.05 \%$ and $12.00 \%)$ and the lowest in NC-7 $(8.43 \%$ and $8.53 \%)$ varieties in both growing seasons (Table 2).

As a result in a two-year average, the stearic acid percentage varied between $3.01-3.30 \%$ in main crop and between $2.80-3.08 \%$ in double crop growing season in different harvesting times. As it can be seen in Table 2, stearic acid percentage of peanut varieties was increased when the harvesting time delayed in both growing seasons. The steraric acid percentage was $3.01 \%$ and $2.80 \%$ in early harvesting it increased to $3.30 \%$ and $3.08 \%$ when the harvesting delayed to 170 DAS and 150 DAS in main and double crop growing seasons, respectively. In atwo year average, the stearic acid percentage of the peanut varieties varied between $2.36-3.47 \%$ in main crop and 2.24-3.21\% in double crop growing seasons. The stearic acid percentage was the highest in Florispan variety $(3.47 \%$ and $3.21 \%)$ and the lowest in G.Green variety $(2.36 \%$ and $2.24 \%)$ in both growing seasons.

Lignoceric acid percentage varied between 1.63-1.80\% and $1.60-1.82 \%$ in main and double crop growing seasons, respectively in a two-year average. Lignoceric acid percentage was decreased when the harvesting time delayed in both growing seasons. As a result, while the lignoceric acid percentage was the $1.80 \%$ and $1.82 \%$ at the early harvesting, it decreased to $1.63 \%$ and $1.60 \%$ when the harvesting time delayed to 170 DAS and 150 DAS in main and double crop growing seasons, respectively. In a two-year average, the lignoceric acid percentage of the peanut varieties varied between 1.49$1.87 \%$ and $1.42-2.00 \%$ in main and double crop growing 
season, respectively. The lignoceric acid percentage was the highes in G.Green $(1.85 \%)$ and Florispan $(1.87 \%)$ varieties in main crop and the lowest in NC-7 (1.49\% and $1.42 \%$ ) in double crop growing seasons (Table 2). Palmitic and lignoseric acids percentage was higher in double crop growing season and the stearic acid was higher in main crop growing season. According to a twoyear average, interaction between the variety and harvesting time for the palmitic, staric and lignoceric acids percentage was statistically significant in both growing seasons.

Fatty acid composition of peanut oils is not constant. Several factors affect the fatty acid content in peanut oil, including variety, seasonal variation, genotype, location, air and soil temperature, planting date, soil nutrient, moisture availability, growing conditions and maturity (How and Young, 1983; Hashim et al., 1993; Dwivedi et al., 1996; Hassan et al., 2005; Isleib et al., 2008; Hassan and Ahmed, 2012 and Chaiyadee et al., 2013).

The saturated fatty acids content in peanut oil were strongly influenced by genotype (Isleib et al., 2008). Oil content and fatty acid composition of peanut has been studied in different cultivars and different environments and it has been reported that the palmitic acid content of peanut cultivars varied between $8.6-14.1 \%$, stearic acid 1.6-3.7\%, arachidic acid 1.2-1.7\% and behenic acid 1.23.5\% (Mozingo et al., 2004; Yav et al., 2008; Onemli, 2012; Chaiyadee et al., 2013; Mzimbiri et al., 2014 and Chowdhury et al., 2015). Significant differences for palmitic, stearic and lignoceric acids percentage among the cultivars are attributable to the genetic makeup and place of their origin (Hassan et al., 2005). These results are in agreement with the findings of Dwivedi et al. (2000), Anderson and Gorbet (2002), Ozcan and Seven (2003), Hassan et al. (2005), Gulluoglu et al. (2016), Sogut et al. (2016) and Arioglu et al. (2018),

\section{Unsaturated Fatty Acids Composition and Oil Quality Values}

The two years average values belonging to unsaturated fatty acids (oleic and linoleic acids) composition and oil quality values $(\mathrm{O} / \mathrm{L}$ and $\mathrm{IV})$ of peanut varieties at different harvesting times and growing seasons have been presented in Table 3.

Table 3. The two years average values belonging to unsaturated fatty acids composition and oil quality values of some peanut varieties at different harvesting times in main and double crop growing seasons.

\begin{tabular}{|c|c|c|c|c|c|c|c|c|c|}
\hline \multicolumn{2}{|c|}{ Harvesting Times (A) } & \multicolumn{2}{|c|}{$\begin{array}{c}\text { Oleic Acid } \\
(\%)\end{array}$} & \multicolumn{2}{|c|}{ Linoleic Acid (\%) } & \multicolumn{2}{|c|}{$\begin{array}{c}\text { Oleic/Linoleic } \\
\text { ratio }(\mathrm{O} / \mathrm{L})\end{array}$} & \multicolumn{2}{|c|}{ Iodin Value (IV) } \\
\hline Main Crop & $\begin{array}{l}\text { Double } \\
\text { Crop }\end{array}$ & $\begin{array}{l}\text { Main } \\
\text { Crop }\end{array}$ & $\begin{array}{l}\text { Double } \\
\text { Crop }\end{array}$ & $\begin{array}{l}\text { Main } \\
\text { Crop }\end{array}$ & $\begin{array}{l}\text { Double } \\
\text { Crop }\end{array}$ & $\begin{array}{l}\text { Main } \\
\text { Crop }\end{array}$ & $\begin{array}{l}\text { Double } \\
\text { Crop }\end{array}$ & $\begin{array}{l}\text { Main } \\
\text { Crop }\end{array}$ & $\begin{array}{c}\text { Double } \\
\text { Crop }\end{array}$ \\
\hline $130 \mathrm{DAS}$ & $110 \mathrm{DAS}$ & 48.06 & 45.85 & 30.05 & 31.35 & 1.60 & 1.46 & 93.39 & 93.74 \\
\hline 140 DAS & 120 DAS & 48.75 & 47.03 & 29.67 & 30.59 & 1.64 & 1.54 & 93.32 & 93.44 \\
\hline 150 DAS & 130 DAS & 49.32 & 47.70 & 29.12 & 30.09 & 1.69 & 1.59 & 92.86 & 93.15 \\
\hline 160 DAS & 140 DAS & 49.96 & 48.50 & 28.65 & 29.50 & 1.74 & 1.64 & 92.60 & 92.81 \\
\hline 170 DAS & $150 \mathrm{DAS}$ & 50.43 & 49.25 & 28.18 & 29.23 & 1.79 & 1.68 & 92.19 & 92.79 \\
\hline $\operatorname{LSD}\left(\% 5_{\mathrm{A}}\right)$ & & 0.017 & 0.017 & 0.008 & 0.010 & 0.15 & 0.36 & 0.05 & 0.82 \\
\hline \multicolumn{10}{|l|}{ Varieties (B) } \\
\hline Halisbey & & 53.78 & 52.18 & 25.46 & 26.08 & 2.11 & 2.00 & 90.36 & 90.05 \\
\hline $\mathrm{NC}-7$ & & 60.45 & 58.99 & 19.84 & 20.91 & 3.05 & 2.82 & 86.36 & 86.96 \\
\hline G. Green & & 48.87 & 47.12 & 29.71 & 30.70 & 1.64 & 1.53 & 93.49 & 93.70 \\
\hline Florispan & & 39.05 & 37.43 & 37.47 & 38.67 & 1.04 & 0.97 & 98.49 & 99.17 \\
\hline G.Red & & 44.37 & 42.62 & 33.18 & 34.42 & 1.34 & 1.24 & 95.63 & 96.28 \\
\hline $\operatorname{LSD}\left(\% 5_{\mathrm{B}}\right)$ & & 0.042 & 0.043 & 0.035 & 0.36 & 1.35 & 1.12 & 0.09 & 0.03 \\
\hline $\operatorname{LSD}\left(\% 5_{\mathrm{AxB}}\right)$ & & 0.094 & 0.095 & 0.079 & 0.080 & 3.01 & 2.50 & 0.17 & 0.06 \\
\hline
\end{tabular}

\section{Unsaturated Fatty Acids Composition}

The major unsaturated fatty acids in peanut oil are oleic (18:1) and linoleic (18:2) acids. As it can be seen in Table 3 , the differences between the harvesting times of the peanut varieties were statistically significant for the oleic and linoleic acids percentage. According to a twoyear average, oleic acid percentage varied between 48.06$50.43 \%$ in main crop and $45.85-49.25 \%$ in double crop growing seasons. The oleic acid percentage of peanut varieties was increased when the harvesting time delayed in both growing seasons. While the oleic acid percentage was $48.06 \%$ and $45.85 \%$ at the early harvesting time, it increased to $50.43 \%$ and $49.25 \%$ at the harvesting 170 DAS and 150 DAS in main and double crop growing season, respectively. Oleic acid percentage of peanut varieties varied between $39.05-60.45 \%$ in main crop and $37.43-58.99 \%$ in double crop growing season in a twoyear average. The differences between the peanut varieties for the oleic acid percentage were significant in main and double crop growing seasons. The oleic acid percentage was the highest in NC-7 $(60.45 \%$ and $58.99 \%)$ and the lowest in Florispan (39.05\% and $37.43 \%$ ) varieties in both growing seasons. As can be seen in Table 3, the oleic acid content was higher in Virginia type varieties than the others market types in main and double crop growing seasons.

Linoleic acid percentage of peanut varieties ranged from $28.18 \%$ to $30.05 \%$ in main crop and from $29.23 \%$ to 
$31.35 \%$ in double crop growing seasons at different harvesting times in a two-year average. Linoleic acid percentage was decreased when the harvesting time delayed in both growing seasons. According to two years result, while the linoleic acid percentage was $30.05 \%$ and $31.35 \%$ in early harvesting, it decreased to $28.18 \%$ and $29.23 \%$ when the harvesting time delayed to $170 \mathrm{DAS}$ and 150 DAS in main and double crop growing seasons, respectively (Table 3 ). The differences between the peanut varieties for the linoleic acid percentage were significant both growing seasons. As it can be seen in Table 3, linoleic acid percentage of peanut varieties varied between $19.84-37.47 \%$ in main crop and $20.91-38.67 \%$ in double crop growing season in a two-year average. The linoleic acid percentage was the highest in Florispan $(37.47 \%$ and $38.67 \%)$ variety and the lowest in NC-7 (19.84\% and $20.91 \%$ ) varieties in both growing seasons. It was observed that the linoleic acid percentage was higher in double crop than in main crop growing season. While the oleic acid percentage of peanut varieties was increasing, the linoleic acid percentage was decreased when the harvesting delayed. According to a two-year average, interaction between the variety and harvesting time for the oleic and linoleic acids percentage was statistically significant in both growing seasons.

Andersen and Gorbet (2002), Gulluoglu et al. (2016) and Arioglu et al. (2018) reported that seed maturity can also influence the fatty acid composition of peanut. The actual impact of seed maturity is dependent on genotype, climatic conditions, and genotype/climate interactions. Lower temperature during the seed development normally is associated with more unsaturated oil due to the increased activity of oleate desaturase which promotes the synthesis of linoleic acid. In general, oleic acid increases and linoleic acid decreases with seed maturity. The increase in oleic acid with seed maturity is normally accompanied by a decrease in palmitic, linoleic, arachidic, eicosenic, behenic and lignoceric acid. Knauft et al. (1986) pointed out that digging delays tended to give peanut oil with higher oleic acid and less linoleic acid. Wolf et al. (1982) reported that fatty acid composition was strongly affected by temperature; linolenic and linoleic acids decreased markedly, whereas oleic acid increased as the temperature increased. Gulluoglu et al. (2016) reported that the oleic and linoleic acids percentage of peanut varieties were varied between 51.54-54.94\% and 24.65$26.78 \%$, respectively at different harvesting times in main crop growing seasons in Cukurova region. Arioglu et al. (2018) reported that the oleic and linoleic acids percentage of peanut varieties were varied between $53.69-57.38 \%$ and 20.74-23.73\%, respectively at different harvesting times in main crop growing seasons in Mediterranean region. Gulluoglu et al. (2016) and Arioglu et al. (2018) indicated that the oleic acid percentage was increased and linoleic acid was decreased when the harvesting times delayed. Asubio et al. (2008), Shin et al. (2010) and Onemli (2012) reported that there was a negative correlation between oleic acid and linoleic acid. Holaday and Pearson (1974) found that higher temperatures during the last 4 weeks before harvest resulted in higher oil and oleic acid content.
How and Young (1983), Dwivedi et al. (2000), Ozcan and Seven (2003) and Wang and Xu (2013) indicated that fatty acid composition of peanut oils has been studied in different cultivars by some researchers and it has been reported that the oleic and linoleic acids content of peanut cultivars varied between $35-65 \%$ and $19-45 \%$, respectively. Arioglu et al. (2018) reported that the oleic and linoleic acids percentage of peanut varieties were varied between $43.84-80.06 \%$ and $2.18-32.05 \%$, respectively in main crop growing season. Onemli (2012) reported that the highest oleic acid percentage was obtained from NC-7 variety. Norden et al. (1987) indicated that the oleic acid content in peanut genotypes can vary from 21 to $85 \%$ and linoleic acid from 2 to $43 \%$. Andersen and Gorbet (2002) concluded that biochemical relationships between variables of fatty acids were more greatly affected by genetic effects than by environmental conditions. Hassan et al. (2005) reported that significant differences for unsaturated fatty acids among peanut cultivars are attributable to the genotype. Baydar and Ipkin (1995), Dwivedi et al. (1996), Dwivedi et al. (2000), Anderson and Gorbet (2002), Ozcan and Seven (2003), Onemli (2012), Gulluoglu et al. (2016) and Arioglu et al. (2018) were found similar results.

\section{Oil Quality Values}

The ratio of oleic acid to linoleic acid (O/L ratio) and iodine value (IV) determine the nutritional quality, storability and shelf-life of peanut oil and its products. A high oleic to linoleic $(\mathrm{O} / \mathrm{L})$ acid ratio $(>10: 1)$ in peanut results an increased self life (up to 10 times) and improved flavor when compared to a normal $\mathrm{O} / \mathrm{L}$ ratio (1.5/1). In addition, the iodine value was used to determine the degree of unsaturated fatty acid and the stability of peanut oil. High $\mathrm{O} / \mathrm{L}$ ratio and low IV value generally indicate good stability and long shelf-life (Young and Worthington, 1974; Yav et al., 2008; Chaiyadee et al., 2013; Chamberlin et al., 2014 and Escobedo et al., 2015).

As it can be seen in Table 3, the differences between the harvesting times for the $\mathrm{O} / \mathrm{L}$ values were statistically significant in both growing seasons. According to a twoyear average, $\mathrm{O} / \mathrm{L}$ values of the peanut varieties varied between 1.60 and 1.79 in main crop and between 1.46 and 1.68 in double crop growing seasons at different harvesting times in a two-year average. $\mathrm{O} / \mathrm{L}$ value of the peanut varieties was increased when the harvesting time delayed in both growing seasons. According to a twoyear result, while the $\mathrm{O} / \mathrm{L}$ value was 1.60 and 1.46 in early harvesting, it increased to 1.79 and 1.68 when the harvesting time delayed to 170 DAS and 150 DAS in main and double crop growing seasons, respectively. As it can be seen in these results, $\mathrm{O} / \mathrm{L}$ ratio increased when the harvesting times were delayed. The reason of $\mathrm{O} / \mathrm{L}$ increases because the oleic acid percentage was increased and the linoleic acid was decreased when the harvesting times were delayed.

Young et al. (1972) and Knauft et al. (1986) pointed out that digging delays tended to give peanut oil with higher oleic acid and less linoleic acid. This relationship 
gave higher $\mathrm{O} / \mathrm{L}$ rations in later diggings, indicating that the oil from these diggings would be more stable. Canavar and Kaynak (2013) reported that oil content and O/L ratios were increased by delaying the harvesting time. Andersen and Gorbet, (2002) reported that, seed maturity can also influence the fatty acid composition of peanut. In general, oleic acid increases and linoleic acid decrease with seed maturity. The increase in oleic acid with seed maturity is normally accompanied by a decrease in linoleic acid. Bovi (1982), Raheja et al. (1987) and Onemli (2012) reported that there was a negative correlation between oleic acid and linoleic acid. Holaday and Pearson (1974) found that higher temperatures during the last 4 weeks before harvest resulted in higher oil and oleic acid content and correspondingly higher $\mathrm{O} / \mathrm{L}$ ratios. Gulluoglu et al. (2016) reported that the O/L ratio of the peanut oil varied between 1.92 and 2.23 at different harvesting times in main crop growing season. The $\mathrm{O} / \mathrm{L}$ ratio was increase when the harvesting delayed.

Significant differences among the cultivars were observed for $\mathrm{O} / \mathrm{L}$ ratio in both growing seasons. $\mathrm{O} / \mathrm{L}$ values of the varieties varied between 1.04-3.05 and 0.972.82 in main and double crop growing seasons, respectively. The highest $\mathrm{O} / \mathrm{L}$ value was found in $\mathrm{NC}-7$ (3.05 and 2.82) and the lowest in Florispan (1.04 and 0.97) varieties compared with rest of cultivars in both growing seasons (Table 3 ). The $\mathrm{O} / \mathrm{L}$ value of the peanut varieties was found higher in main crop than in double crop growing season. Oleic and Linoleic acids percentage of peanut varieties were found different. For these reasons, $\mathrm{O} / \mathrm{L}$ ratio of the peanut varieties was found different. Young et al. (1972) grew eight different peanut cultivars in Oklahoma for one year to assess effects of digging date on oil quality. They dug at five different digging dates, starting with 113 DAP for early maturing and 120 DAP for later maturing genotypes. Digging delays tended to give peanut oil with higher stearic and oleic acid and less linoleic acid. This relationship gave higher $\mathrm{O} / \mathrm{L}$ ratios in later diggings, indicating that the oil from these diggings would be more stable. Hassan et al. (2005) reported that significant differences for unsaturated fatty acids and $\mathrm{O} / \mathrm{L}$ ratio among peanut cultivars are attributable to the genotype. Onemli (2012) reported that there was a negative correlation between oleic acid and linoleic acid. Young et al. (1972), How and Young (1983), Hashim et al. (1993), Hinds (1995), Andersen and Gorbet (2002), Chaiyadee et al. (2013), Chamberline et al. (2014), Escobedo et al. (2015), Gulluoglu et al. (2016) and Arioglu et al. (2018) were indicated similar results.

Iodine values (IV) of the peanut oils were calculated using the $(\%$ oleic acid $x$ 0.8601) + (\% linoleic acid $\mathrm{x}$ 1.7321 ) equation given by Chowdhury et al. (2015). IV is important quality factor in peanut oil. Chaiyadee et al. (2013), Brown et al. (1975) and Yav et al. (2008) reported that the ratio of oleic acid to linoleic acid $(\mathrm{O} / \mathrm{L}$ ratio) and iodine value determine the quality, storability and shelflife of peanut oil and its products. In addition, the iodine value (IV) was used to determine the degree of unsaturated fatty acid and the stability of peanut oil. High- oleic peanut has longer self-life than low-oleic peanut and it has better flavor quality or stability than low-oleic peanut. Worthington et al. (1972) and Young and Manson (1972) indicated that Iodine value indicates of the stability and self life of peanut oil. Low iodine value generally indicates good stability and long shelf-life.

According to a two-year average, the iodine values of the peanut varieties varied between 92.19-93.39 in main crop and 92.79-93.74 in double crop growing seasons at different harvesting times (Table 3). Iodine value was decrease when the harvesting delayed in both growing seasons. Iodine value was the 93.39 at the harvesting 130 DAS, it decreased to 92.19 when the harvesting delayed to 170 DAS in main crop growing seasons. Similar results were obtained in double crop growing season. Knauft et al. (1986) pointed out that digging delays tended to give peanut oil with higher oleic acid and less linoleic acid. This relationship gave higher $\mathrm{O} / \mathrm{L}$ ratios in later diggings, indicating that the oil from these diggings would be more stable. Andersen and Gorbet, (2002) reported that, seed maturity can also influence the fatty acid composition of peanut. In general, oleic acid increases and linoleic acid decrease with seed maturity. The increase in oleic acid with seed maturity is normally accompanied by a decrease in linoleic acid. Young and Worthington (1974), Dwivedi et al. (1996) and Isleib et al. (2008) reported that fatty acid composition of peanut seed oil influenced by varietal and seasonal variation, genotypic variation, air and soil temperature, planting date, soil nutrient, growing conditions and maturity. Iodine value was found higher in double crop than in main crop growing season. Linoleic acid percentage was higher in double crop than in main crop. For this reason, Iodine value was found higher in double crop growing season.

The differences between the peanut varieties for the iodine value were found statistically significant in both growing seasons. The iodine value of the peanut varieties was varied between 86.36-98.49 in main crop and 86.9699.17 in double crop growing seasons. The iodine value was the highest in Florispan (98.49 and 99.17) and the lowest in NC-7 (86.36 and 86.96) varieties in both growing seasons (Table 3 ). Linoleic acid percentage was the lowest in NC-7 and the highest in Florispan varieties. High linoleic acid percentage increases the iodine value (\% Linoleic acid $x$ 1.7321). Linoleic and oleic acids percentage was the important factors for indicating the iodine value. Andersen and Gorbet (2002) concluded that biochemical relationships between variables of fatty acids were more greatly affected by genetic effects than by environmental conditions. The reason for the differences between the varieties for the iodine value was them having different oleic and linoleic acids content. These results are in agreement with the findings of How and Young (1983), Raheja et al. (1987), Hashim et al. (1993), Hinds (1995), Andersen and Gorbet (2002), Chaiyadee et al. (2013), Chamberline et al. (2014), Chowdhury et al. (2015), Gulluoglu et al. (2016) and Arioglu et al. (2018) were indicated similar results. 


\section{CONCLUSION}

The differences between the harvesting times and peanut varieties were found statistically significant fatty acids percentage and oil quality values. Palmitic acid, lignoceric acid, linoleic acid percentage and iodine value were decreased and oil content, stearic acid, oleic acid percentage and $\mathrm{O} / \mathrm{L}$ ratio were increased when the harvesting times delayed. Stearic acid and oleic acid percentage and $\mathrm{O} / \mathrm{L}$ ratio was higher in main crop growing season and oil content, linoleic acid percentage and iodine value was higher in double crop growing season.

The ratio of oleic acid to linoleic acid (O/L ratio) and iodine value (IV) determine the nutritional quality, storability and shelf-life of peanut oil and its products. A high oleic to linoleic $(\mathrm{O} / \mathrm{L})$ acid ratio $(>10: 1)$ in peanut results an increased self life (up to 10 times) and improved flavor when compared to a normal $\mathrm{O} / \mathrm{L}$ ratio (1.5:1). In addition, the iodine value was used to determine the degree of unsaturated fatty acid and the stability of peanut oil. High $\mathrm{O} / \mathrm{L}$ ratio and low IV value generally indicate good stability and long shelf-life. O/L ratio was high and iodine value was low in main crop growing season. These results showed that the nutritional quality, storability and shelf-life of peanut oil and its products were better in main crop than double crop peanut production.

\section{LITERATURE CITED}

Ahmed E.H. and C.T. Young. 1982. Composition, nutrition and flavor of peanut. in:peanut science and technology, Ed. By H.E. Pattee, and C.T Young. American Peanut Research and Education Society, Inc. Yoakum, pp. 655-687

Andersen P.C. and D.W. Gorbet. 2002. Influence of year and planting date on fatty acid chemistry of high oleic acid and normal peanut genotypes. J. Agric. Food Chem. 50:12981305

Anonymous, 2017a. FAO Production Year Book. Availlabe from www.fao.org.

Anonymous. 2017b. The Meteorological Data for Adana. The Turkish State Meteorological Service Adana Regional Directorship, 2015, 2016 and Long Term.

AOCS. 1989. Official and Recommended Methods. American Oil Chemists' Society Press. Champaing, IL, USA

Arioglu H. H. 2014. The oil seed crops growing and breeding. The Publication of University of Cukurova, Faculty of Agriculture, No:A-70, 204 p. Adana-Turkey

Arioglu H., H. Bakal, L. Gulluoglu, B. Onat and C. Kurt. 2018. The effect of harvesting dates on some agronomic and quality characteristics of peanut (Arachis hypogaea L.) varieties grown as a main crop in Mediterranean Region (Turkey). Turkish journal of Field Crops 23(1):27-37, DOİ: $10.17557 / \mathrm{tjfc} .414856$

Asibuo J.Y., R.Akromah, H.K Adu-Dapaah, O.S. Kantanka. 2008. Evaluation of nutritional quality of groundnut (Arachis hypogaea L.) from Ghana. African Journal of Food Agriculture Nutrition and Development 8: 133-149.

Baydar H., B. İpkin. 1995. The Comparation of Oil Yield and Oil Quality Criteria of Virginia, Spanish and Valancia Type Peanut (Arachis hypogaea L.) Varieties. Akdeniz University, The Journal of Agricultural Faculty, 8 (1), 81-90.

Bovi M.L.A. 1982. Genotypic and environmental effect on fatty acid composition, iodine value and oil content of peanut (Arachis hypogea L.) Ph.D. Dissertation. University of Florida, p. 119.
Brown D.F., M.C. Carl, F.M. Karl and G.D. James. 1975. Effect of variety, growing location and their interaction on the fatty acid composition of peanut. J. Food Sci. 40:1055-1060

Caliskan S., M.E. Caliskan, M. Arslan and H. Arioglu. 2008. Effects of sowing date and growth duration on growth and yield of groundnut in a Mediterranean-Type environment in Turkey. Field Crops Res. 105:131-140

Canavar O. and M.A. Kaynak. 2013. Determination of yield and yield components and seed quality of peanuts (Arachis hypogaea L.) at different harvest times. Int. J. of Agronomy and Plant Production 4(S):3791-3803

Chaiyadee S., S. Jogloy, P. Songsri, N. Singkham, N. Vorasoot, P. Sawatsitang, C.C. Holbrook and A. Patanothai. 2013. Soil moisture affects fatty acids and oil quality parameters in peanut. Int. J. of Plant Production 7(1):81-96

Chamberlin K.D., N.A. Barkley, B.L. Tillman, J.W. Dillwith, R. Madden, M.E. Payton and R.S. Bennett. 2014. A comparison of methods used to determine the oleic/linoleic acid ratio in cultivated peanut (Arachis hypogaea L.). Agricultral Science 5(3):227-237.

Chowdhury F.N., D. Hossain, M. Hosen and S. Rahman. 2015. Comperative study on chemical composition of five varieties of groundnut (Arachis Hypogaea L.). World J. of Agricultural Science 11(5)247-254

Court W.A., R.C. Roy and J.G. Hendel. 1984. Effect of harvest date on agronomic and chemical characteristics of ontario peanuts. Canadian J. Plant Science 64:521-528

Dwivedi S.L., S.N. Nigam and R.C. Nageswara Rao. 2000. Photoperiod effects on seed quality traits in peanut. Crop Sci. 40:1223-1227.

Dwivedi S.L., S.N. Nigam, R. Jambunathan, K.L. Sahrawat, G.V.S. Nagabhushanam and K. Raghunath. 1996. Effect of genotypes and environments on oil and oil quality parameters and their correlation in peanut (Arachis hypogaea L.). Peanut Science 20:84-89

Dwivedi SL, D.V.R. Reddy, S.N. Nigam, G.V. Ranga Rao, J.A. Wightman, P.W. Amin, G.V.S. Nagabhushanam, A.S. Reddy, E. Scholberg, V.M. Ramraj. 1993 Registration of ICGV 86031 peanut germplasm. Crop Science 33:220

Escobedo R.V., P.H. Luna, I.J.C. Torres, A.O. Mopreno and M.C.R. Ramirez. 2015. Physicochemical properties and fatty acid profile of eight peanut varieties grown in Mexico. Journal of Food 13(2):300-304

Golukcu M.,R. Toker, H. Tokgoz and A. Kadiroglu. 2016. Oil Content and Fatty Acid Composition of Some Peanut (Arachis hypogaea L.) Cultivars Grown in Antalya. Food, 41(1):31-36

Gulluoglu L., H. Bakal, B. Onat, C. Kurt and H. Arioglu. 2017. Comparison of agronomic and quality characteristics of some peanut (Arachis hypogaea L.) varieties grown as main and double crop in Mediterranean Region. Turkish Journal of Field Crops 22(2):166-177, DOI:10.17557/TJFC.356208

Gulluoglu L., H. Bakal, B. Onat, C.Kurt and H. Arioglu. 2016. The effect of harvesting dates on yield and some agronomic and quality characteristics of peanut grown in Mediterranean Region (Turkey). Turkish Journal of Field Crops 21(2): $224-$ 232

Harris D., R.B. Matthews, R.C. Nageswara Rao and J.H. Williams. 2008. The physiological basis for yield differences between four genotypes of groundnut (Arachis hypogaea L.) in response to drought. Experimental Agriculture 24: 215226.

Hashim J.B., P.E. Koehler. R.R. Eitenmiller and C.K. Kvien. 1993. Fatty acid composition and tocopherol content of drought stressed Florunner peanuts. Peanut Sci. 20:21-24 
Hassan F. and M. Ahmed. 2012. Oil and fatty acid composition of peanut cultivars grown in pakistan. Pakistan J. of Botany. 44(2):627-630

Hassan F., A. Manaf and M. Ejaz. 2005. Determinants of oil and fatty acid accumulation in peanut. Int. J. of Agriculture and Biology. 7(6):895-899

Hinds M.J. 1995. Fatty acid composition of caribbean-grown peanuts (Arachis hypogaea L.) at three maturity stages. Food Chemistry 53:7-14

Holaday C.E. and J.L. Pearson.1974. Effects of genotype and production area on the fatty acid composition, total oil and protein in peanuts. Journal of Food Science 39(6):1206-1209

How J.S.L. and C.T. Young. 1983. Comparison of fatty acid content of imported peanuts. JAOCS 6(5)945-947

Isleib T.G., B.L. Tilman, H.E. Patte, T.H. Sanders, K.W. Hendrix and L.O. Dean. 2008. Genotype-by-environment interaction for seed composition traits of breeding lines in the uniform peanut performance test. Peanut Science 35:130138

Knauft A., A.J. Norden and D.W. Gorbet. 1986. The effect of three digging dates on oil quality, yield, and grade of five peanut genotypes grown without leaf spot control. Peanut Science 13: 86-89

Kris-Etherton, P. M., T. A. Pearson, Y. Wan, R. L. Hargrove, K. Moriarty and V. Fishell, 1999. High-monounsaturated fatty aciddiets lower both plasma cholesterol and triacylglycerol concentra-tion.American Journal of Clinical Nutrition 70: 1009-101

Lue K.C., M.S. Yeh, K.H. Yang and H.S. Lu. 1997. Effects of genotype, population density and harvest date on yield and quality of peanut. J. Of Agric. Res. China. 46(2):116-131

Mozingo R.W., S.F. O'Keefe, T.H. Sanders and K.W. Hendrix. 2004. Improving shelf life of roasted and salted inshell peanuts using high oleic fatty acid chemistry. Peanut Sci. 31:40-45. doi:10.3146/ pnut.31.1.0009

Mzimbiri R., A.M. Shi, H. Liu and Q. Wang. 2014. A review: peanut fatty acids determination using hyper spectroscopy imagine and its significance on food quality and safety. Food Science and Quality Management 28:90-97

Norden A.J., D.W. Gorbet, D. A. Knauft and C.Y.Young. 1987. Variability in oilquality among peanut genotypes in the Florida breeding programe. Peanut Science, 14:7-11

Onemli F. 2012. Impact of climate changes on oil fatty acid composition of peanut (Arachis hypogaea L.) in three market classes. Chilean J. Agri. Res. 72(4):383-488

Ozcan M. and S. Seven. 2003. Physical and chemical analysis and fatty acid composition of peanut, peanut oil and peanut butter from COM and NC-7 cultivars. Grasas Y Aceites 54(1):12-18

Raheja R.K., S.K. Battai, K.L. Ahuja, K.S. Labana and M. Singh. 1987. Comparison of oil content and fatty acid composition of peanut genotypes differing in growth habit. Plant Foods for Human Nutrition 37:103-108

Sanders T.H., H.A. Pate, J.R. Vercellotti and K.I. Bett. 1995. Advances in peanut flovor quality. P.528-553. In H.E. Pattee and H.T. Stalker (eds.) Advances in Peanut Science. Amer. Peanut Res. Education Soc. Inc., Stillwarer. Okla.

Sarkees N.A. 2015. Effect of sowing dates on development, seed yield and quality of some peanut (Arachis hypogaea L.) genotypes. Jordan J. Of Agricultural Sciences 11(2):367-380

Sattayarak S. 1997. Effects of harvesting dates on different characters and seed quality of peanut grown in Southern Thailand. http://Agris.Fao.Org/Agris-Search/.Do Recordid = TH2000000950

Savage G.P. and J.I. Keenan. 1994. The composition and nutritive value of groundnut kernels. in: smart, j., ed., the groundnut crop: Scientific Basis for Improvement, Chapman and Hall, London, 173-213.

Shin C.M., S.J. Compadre, R.A. Maleki, H. Kopper, S.K. Sam pson A.W. Huang, G.A. BurksBannon. 2010. Biochemical and structural analysis of the 1ge binding sites on ara $\mathrm{H} 1$, an abundant and highly allergenic peanut Protein J. Biol. Chem. 273 (1998), pp. 13753-13759.

Sogut T., F. Ozturk, S. Kiz1l. 2016. Effect of sowing time on peanut (Arachis hypogaea L) cultivars yield, yield components, oil and protein content. Scientific Papers. Series A. Agronomy, Vol. LIX:415-419

Wang Z. and Z. Xu. 2013. Effect of peanut hull biochar on amelioration of typical orchard acidic soil in northern china. Periodical Ocean Univ. China 43 (8), 86-91.

Wolf R.B., J.F. Cavins., R.Kleiman, L.T. Black.1982. Effect of temperature on soybean seed constituents: oil, protein, fatty acids, amino acids and sugars. J. of the American Oil Chemists' Society (JAOCS) Vol.59: (5):230-232

Worthington R. E., R. O. Hammons. and A. J. R.1lison. 1972. Varietal differences and seasonal effects on fatty acid composition and stability of oil from 82. Peanut Genotypes. J. Agric. Food Chem. 20: 727 .

Yav A.S., A. Richard, A.K. Osei, A.D.H. Kofi, O.D. Seth and A. Adelaide. 2008. Chemical composition of groundnut, (Arachis hypogaea L.) Landraces. African J. Of Biotechnology 7(13):2203-2208

Young C. T., M.E. Manson, R.S. Matlock and G.R. Waller. 1972. Effect of maturity on the fatty acid composition of eight varieties of peanut grown at parkins, Oklahoma in 1968. JAOCS, 49:314-317

Young C.T. and M.E. Manson. 1972. Free arginine content of peanut (Arachis hypogaea L.) as a measure of seed maturity. Journal of Food Science 37:722-725

Young C.Y. and R.E. Worthington, 1974. Fatty acid composition of Spanish peanut oil as influenced by planting location, Soil Moisture Conditions, Variety, and Season. AOCS 51:312315 . 